Arch. Tierz., Dummerstorf 49 (2006) 3, 259-268

Humboldt-University of Berlin, Agricultural and Horticultural Faculty, Institute of Animal Sciences, Department of Breeding Biology and Molecular Genetics, Berlin, Germany

BERND BUSKE, INA STERNSTEIN, MONIKA REIßMANN, PETER REINECKE and

GUDRUN BROCKMANN

\title{
Analysis of association of GPX5, FUT1 and ESR2 genotypes with litter size in a commercial pig cross population
}

\author{
Dedicated to Professor Dr. Gerhard Seeland on the occasion of his $65^{\text {th }}$ birthday
}

\begin{abstract}
The aim of this study was to investigate, if special genotypes of the genes glutathione peroxidase 5 (GPX5), fucosyltransferase 1 (FUT1) and estrogen receptor 2 (ESR2) are associated with litter size in a commercial pig cross population. For this purpose, a total of $123 \mathrm{~F}_{2}$ sows were divided into two extreme performance groups, one with a high litter size ( $n=61, \geq 14.3$ piglets per litter) and one with a low litter size ( $n=62, \leq 11.3$ piglets per litter) and genotyped using PCR-RFLP methods. The Chi-square test was used in order to investigate, if a special genotype occurs significantly more often in one of the two performance groups $(p<0.05)$. Whereas no association was found between different ESR2 or GPX5 genotypes with one of the two performance groups, the number of sows with AB genotypes at the FUT1 gene was significantly increased in the high performance group in comparison to the low performance group.
\end{abstract}

Key Words: candidate gene, ESR2, FUT1, GPX5, litter size, pigs, reproductive trait, two-tail analysis

\section{Zusammenfassung}

Titel der Arbeit: Untersuchung der GPX5, FUT1 und ESR2 Genotypen auf Assoziation zu Wurfgröße bei einer kommerziellen Zuchtsauen-Population

Ziel dieser Untersuchung war es, die Gene Glutathion-Peroxidase 5 (GPX5), Fucosyltransferase 1 (FUT1) und Östrogenrezeptor 2 (ESR2) auf Assoziation zu Wurfgröße bei einer kommerziellen Zuchtsauen-Population zu untersuchen. $123 \mathrm{~F}_{2}$ Sauen wurden in zwei extreme Leistungsgruppen aufgeteilt, eine mit hoher Wurfgröße ( $\mathrm{n}=$ $61, \geq 14.3$ Ferkel pro Wurf) und eine mit niedriger Wurfgröße ( $n=62$, $\leq 11.3$ Ferkel pro Wurf) und mittels PCRRFLP Methode genotypisiert. Unter Verwendung des Chi-Quadrat-Tests wurde geprüft, ob ein bestimmter Genotyp signifikant $(\mathrm{p}<0.05)$ mit einer der beiden Leistungsgruppen assoziiert ist. Während die beobachtete Genotypenverteilung der Gene ESR2 und GPX5 in den beiden Leistungsgruppen zu keinen signifikanten Unterschieden führte, waren Sauen des Genotyps AB des Gens FUT1 überwiegend in der Hochleistungsgruppe anzutreffen.

Schlüsselwörter: Kandidatengen, ESR2, FUT1, GPX5, Schweine, Reproduktionsmerkmal, „two-tail“ Analyse, Wurfgröße

\section{Introduction}

The genetical improvement of litter size in swine is of expanding interest for pig producers mainly because ameliorations due to feeding regime and housing systems are limited. It has been observed, that up to the middle of the nineties in the past century, improvements were first of all made concerning meat quality. This led to a stagnancy, and even in some cases to a decrease of litter size especially in swine production (KISNER et al., 1995). Therefore, an improvement of fecundity in swine is desirable. Selection programmes, however, are almost only based on phenotypical 
traits, which are laborious, expensive and especially in pig production time consuming. Since a few years, marker assisted selection (MAS), employed in conjunction with traditional selection methods has been in progress to increase litter size in swine. One marker, which is used in commercial pig production, is the estrogen receptor gene 1 (ESR1), and ROTHSCHILD et al. (1996) were the first who observed an association between ESR1 genotypes and litter size in swine. However, so far, there are a lot of inconsistent studies with regard to influence on the ESR1 gene on fecundity parameters in swine (SHORT et al., 1997; DEPUYDT et al., 1999; DRÖGEMÜLLER et al., 1999; KMIEĆ et al., 2002; GIBSON et al., 2002; VAN RENS and VAN DER LENDE, 2002; MATOUŠEK et al., 2003; GOLIÁŠOVÁ and WOLF, 2004; HORÁK et al., 2005; HOROGH et al., 2005; WANG et al., 2006). Therefore, additional candidate genes with potential influence on litter size are studied.

The glutathione peroxidase 5 gene (GPX5) on SSC7 is located in a chromosomal region in which several quantitative trait loci (QTL) for reproductive traits in swine, such as uterine capacity, ovulation rate and litter size have been detected. Linkage analyses of GPX5 showed that this gene is closely linked to the major histocompatibility complex (MHC), which has been suggested to have an effect on reproductive traits in swine (VAIMAN et al., 1998; BUSKE et al., 2005).

The fucosyltransferase 1 gene (FUT1) on SSC6 is also located in a chromosomal region which is associated with litter size in swine. Actually, the FUT1 gene has been determined as a candidate gene for the Escherichia coli F18 receptor locus (MEIJERINK et al., 1997) and an association with oedema disease, diarrhea, and thus an association with animal health was severalfold observed. Because animal health is strongly attended with fecundity, FUT1 could also serve as a candidate gene for litter size in swine (HORÁK et al., 2005).

Concerning estrogen receptors, there are at least two different classes, and MUÑOZ et al. (2004) mapped the estrogen receptor 2 (ESR2) gene at the telomeric end on the $q$ arm of SSC1 in contrast to the ESR1 gene, which is located at the telomeric end on the $\mathrm{p}$ arm of SSC1. The polymorphism in the coding region of exon 5 in the ESR2 gene leads to an amino acid substitution (MET $\rightarrow \mathrm{VAL}$ ) in the hormone binding domain, which is critical for its role as transcription factor. Moreover, the ESR2 gene has been characterized in the rat, mouse and human, and several studies suggest that this receptor displays a high binding affinity to estrogens and therefore might be involved in ovarian follicular growth and development at periimplantation (KOWALSKI et al., 2002). Hence, ESR2 could also serve as a candidate gene for litter size in swine.

Therefore, the aim of this study was to investigate, whether the candidate genes GPX5, FUT1 and ESR2 are associated with litter size in swine in a commercial population. In most cases, association studies were conducted by using a variable number of sows of a resource population. In contrast, we used sows of two extreme performance groups with high and low litter size (two-tail analysis) which were kept in a commercial sow farm.

\section{Animals}

\section{Material and Methods}

Investigations were performed with a commercial pig population from a German sow farm (Polkenberg, Sachsen, Germany). $447 \mathrm{~F}_{2}$-sows of a cross between (Large White $\mathrm{x}$ Landrace) sows $\mathrm{x}$ Leicoma boars that had four litters at minimum represented the basic 
population. Average litter size of these sows was 13.1 piglets per litter according to the number of total newborn (TNB) piglets from the second to the fourth litter. From this basic population, two extreme performance groups were formed comprising $14 \%$ best and $14 \%$ worst sows, according to the number of TNB piglets. The high performance group consisted of 61 sows with at least averaged 14.3 piglets per litter from the second to the fourth litter whereas the low performance group consisted of 62 sows with less than averaged 11.3 piglets per litter from the second to the fourth litter (Table 1). The first litter was ignored, because in general, first litters are more uneven than the following litters. About $20 \%$ of the 123 selected sows were full-sibs. It was ensured, that there was no significant accumulation of these sows in one of the two performance groups. The rest of the sows were half-sibs or unrelated. All sows were mated with Piétrain boars by artificial insemination with a constant amount of fresh sperm. The age of first insemination of the sows, as well as feeding and housing regime were kept constant. A total of 76 boars were distributed randomly to the sows of both performance groups in order to prevent significant paternal influence on litter size. Directly after farrowing, TNB and the number of born alive (NBA) piglets were recorded. DNA of sows was obtained from ear chondral tissue and was isolated according to standard methods.

Table 1

Litter size parameters of selected and genotyped sows of two performance groups (Wurfgröße der ausgewählten und genotypisierten Sauen der beiden Leistungsgruppen)

\begin{tabular}{lccccccccc}
\hline Performance group & Number of $\mathrm{F}_{2}$-sows & \multicolumn{5}{c}{ Litter size $\left(2^{\text {nd }}-4^{\text {th }}\right.$ litter $)$} \\
& & \multicolumn{3}{c}{ TNB } & \multicolumn{3}{c}{ NBA } \\
& & Mean & SD & Range & Mean & SD & Range \\
\hline High & 61 & 15.73 & 2.24 & $12-24$ & 14.10 & 2.13 & $9-19$ \\
Low & 62 & 10.39 & 2.44 & $3-14$ & 9.83 & 2.31 & $3-14$ \\
\hline
\end{tabular}

TNB = Total number born; NBA = Number born alive

\section{Genotyping}

The gene variants were amplified and distinguished according to standard PCR-RFLP methods with small modifications in reference to the original literature (Table 2).

Table 2

Different PCR-RFLP parameters for the genes GPX5, FUT1 and ESR2 (Unterschiedliche PCR-RFLP Parameter für die Gene GPX5, FUT1 und ESR2)

\begin{tabular}{|c|c|c|c|c|}
\hline $\begin{array}{l}\text { Gene } \\
\text { Access. no. }\end{array}$ & Primer sequence (forward and reverse) 5' to 3' & $\begin{array}{l}\mathrm{MgCl}_{2} \\
(\mathrm{mM})\end{array}$ & $\begin{array}{l}\text { Annealing } \\
\text { temp. }\left({ }^{\circ} \mathrm{C}\right) \\
\end{array}$ & $\begin{array}{l}\text { Restriction } \\
\text { enzyme (U) }\end{array}$ \\
\hline $\begin{array}{l}\text { GPX }^{1} \\
\text { AF124818 }\end{array}$ & $\begin{array}{l}\text { TTC ATG TAG AAC TTA TTT CTG } \\
\text { TGA CTT ACC CAT TCT TCA G }\end{array}$ & 2.0 & 51 & $\begin{array}{l}\text { Hinf1 } \\
10\end{array}$ \\
\hline $\begin{array}{l}\text { FUT1 }^{2} \\
\text { U70883 }\end{array}$ & $\begin{array}{l}\text { CTG CCT GAA CGT CTA TCA AGA TC } \\
\text { CTT CAG CCA GGG CTC CTT TAA G }\end{array}$ & 2.5 & 56 & $\begin{array}{c}\text { Hha1 } \\
2\end{array}$ \\
\hline $\begin{array}{l}\text { ESR2 }^{3} \\
\text { AF164957 }\end{array}$ & $\begin{array}{l}\text { AAA ATA CTG ATA CCC ACC CCA CAT } \\
\text { CGC CAC ATC AGC CCC ACC AT }\end{array}$ & 2.0 & 61 & $\begin{array}{l}\text { Hsp92II } \\
5\end{array}$ \\
\hline
\end{tabular}

For the PCR, all genes were amplified separately in a total reaction volume of $25 \mu \mathrm{l}$ containing approximately 75 to $150 \mathrm{ng}$ of genomic DNA, 1 x Taq reaction buffer 
without $\mathrm{MgCl}_{2}, 0.2 \mathrm{mM}$ dNTPs, $0.2 \mu \mathrm{M}$ of each primer, appropriate amount of $\mathrm{MgCl}_{2}$ (Table 2), and $1 \mathrm{U}$ Taq DNA polymerase (Genaxxon, Germany). After denaturation at $94^{\circ} \mathrm{C}$ for $2 \mathrm{~min}, 35$ amplification cycles comprising denaturation at $94^{\circ} \mathrm{C}$ for $1 \mathrm{~min}$, annealing at appropriate temperature (Table 2) for $30 \mathrm{~s}$, and extension at $72^{\circ} \mathrm{C}$ for $40 \mathrm{~s}$ were performed followed by a final 5-min extension step at $72^{\circ} \mathrm{C}$.

After the amplification of the genes, PCR products were incubated with the appropriate restriction enzyme (Table 2) at $37^{\circ} \mathrm{C}$ for $4 \mathrm{~h}$ in order to show the gene variants. DNA-fragments were separated on $2 \%$ agarose-gels. Table 3 shows the expected fragment length of the different genotypes for the investigated genes.

Table 3

Fragment length in basepairs of the genotypes for the GPX5, FUT1 and ESR2 genes (Fragmentlängen in Basenpaaren der Genotypen für die Gene GPX5, FUT1 und ESR2)

\begin{tabular}{|c|c|c|c|c|c|}
\hline \multirow[t]{2}{*}{ Gene } & \multirow[t]{2}{*}{ PCR-product (bp) } & \multicolumn{3}{|c|}{ Fragment length of genotypes (bp) } & \multirow[t]{2}{*}{ Remarks } \\
\hline & & AA & $\mathrm{AB}$ & $\mathrm{BB}$ & \\
\hline GPX5 & 501 & $\begin{array}{c}\frac{298}{33}, 94,53 \\
3,23\end{array}$ & $\begin{array}{c}\frac{298}{64}, \frac{234}{53,33}, 9 \\
23\end{array}$ & $\begin{array}{c}\frac{234}{53}, 94,64 \\
33,23\end{array}$ & $23,33,53$ and 64 are not visible \\
\hline FUT1 & 421 & $\underline{328}, 93$ & $\underline{328}, \frac{241}{87}, 93$ & $\underline{241}, 93,87$ & 87 and 93 are inseparable \\
\hline ESR2 & 218 & $\underline{202}, 16$ & $\underline{202}, \frac{142}{16}, 60$ & $\underline{142}, 60,16$ & 16 and 60 are not visible \\
\hline
\end{tabular}

Underlined fragments: main fragments in order to distinguish genotypes

\section{Statistical analyses}

Firstly, the correlation between TNB and the number of NBA piglets for each performance group was calculated by using the Pearson's Correlation Coefficient ( $r$ ). Afterwards, it was investigated, if a special genotype occurs significantly more often in one of the two performance groups $(p<0.05)$. For this purpose, the Chi-square test with the extension of the Fisher's Exact test was used. The latter one was carried out in order to determine the exact p-values for the expected frequencies of the genotyped sows, when the expected frequencies were smaller than 5 in at least one class. The statistical analyses were performed with the SPSS programme (version 12.0).

\section{Results}

Development of the TNB and the number of NBA piglets in the two performance groups

The Figure shows the development of litter size in the two extreme performance groups of the sows from litter number 1 up to litter number 4 . Whereas there is no remarkable difference between the two extreme performance groups for the first litter, both performance groups differed considerably amount in the following litters for TNB and the number of NBA piglets, respectively.

Correlation between the TNB and the number of NBA piglets in the two performance groups

Table 4 shows the mean values for litter size and the coefficients of correlation $(r)$ between TNB and NBA piglets for the two extreme performance groups for the litters 1 to 4 and for all 4 litters. 


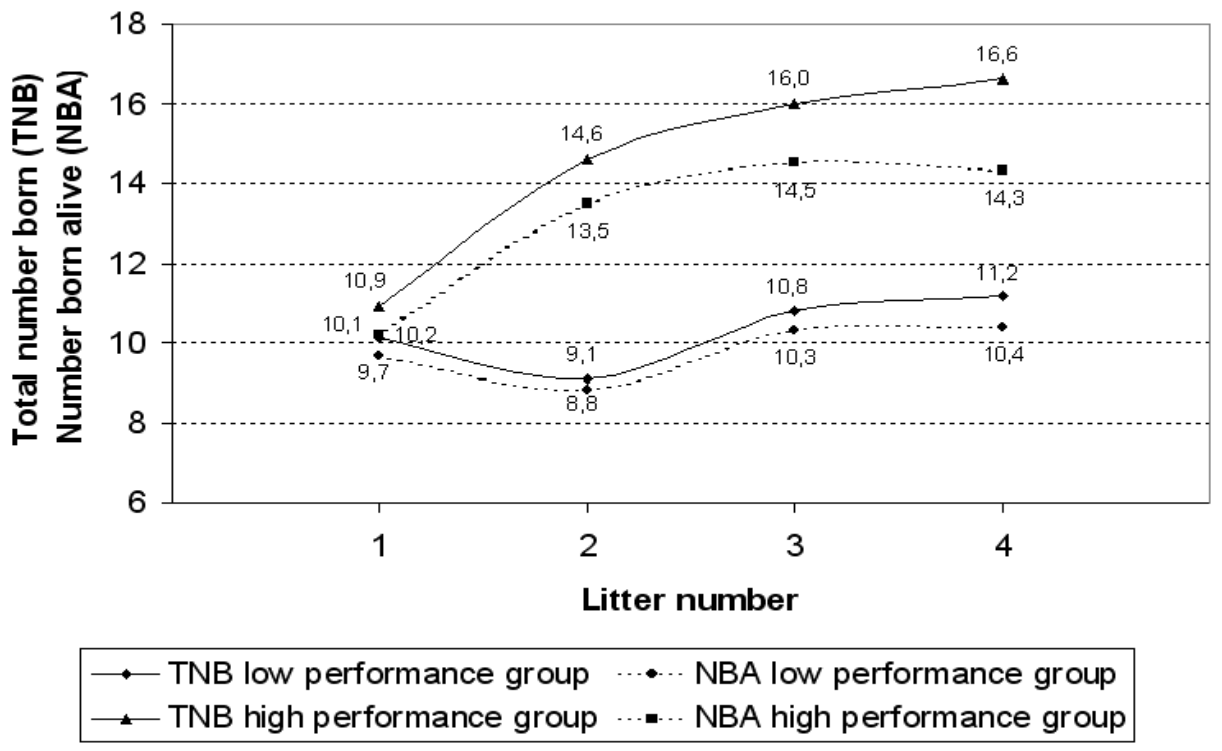

Figure: Development of litter size in dependency of the litter number in the two performance groups (Entwicklung der Wurfgröße in Abhängigkeit von der Wurfnummer in den beiden Leistungsgruppen)

Table 4

Mean values for TNB and NBA piglets and coefficients of correlation $(r)$ between TNB and NBA piglets for the litters 1 to 4 for sows in the two performance groups (Mittelwerte der Wurfleistung sowie Korrelationskoeffizienten ( $r$ ) zwischen insgesamt und lebend geborenen Ferkel der Würfe 1 bis 4 der Sauen in den beiden Leistungsgruppen)

\begin{tabular}{|c|c|c|c|c|c|c|c|c|c|c|}
\hline \multirow[b]{4}{*}{$\begin{array}{c}\text { Litter } \\
\text { no. }\end{array}$} & \multicolumn{10}{|c|}{$\mathrm{F}_{2}$-sows $(\mathrm{N}=123)$} \\
\hline & \multicolumn{5}{|c|}{ Low performance group (N=62) } & \multicolumn{5}{|c|}{ High performance group (N=61) } \\
\hline & \multicolumn{2}{|c|}{ TNB } & \multicolumn{2}{|c|}{ NBA } & \multirow[b]{2}{*}{$r$} & \multicolumn{2}{|c|}{ TNB } & \multicolumn{2}{|c|}{ NBA } & \multirow[b]{2}{*}{$r$} \\
\hline & Mean & SD & Mean & SD & & Mean & SD & Mean & SD & \\
\hline 1 & 10.1 & 3.13 & 9.7 & 3.10 & 0.972 & 10.9 & 3.02 & 10.2 & 2.91 & 0.924 \\
\hline 2 & 9.1 & 2.79 & 8.8 & 2.68 & 0.971 & 14.6 & 2.16 & 13.5 & 1.87 & 0.720 \\
\hline 3 & 10.8 & 2.06 & 10.3 & 1.86 & 0.929 & 16.0 & 2.06 & 14.5 & 2.26 & 0.662 \\
\hline 4 & 11.2 & 1.91 & 10.4 & 1.95 & 0.860 & 16.6 & 2.26 & 14.3 & 2.17 & 0.577 \\
\hline $1-4$ & 10.3 & 2.63 & 9.8 & 2.53 & 0.950 & 14.5 & 3.23 & 13.1 & 2.89 & 0.845 \\
\hline $2-4$ & 10.4 & 2.44 & 9.8 & 2.31 & 0.938 & 15.7 & 2.24 & 14.1 & 2.13 & 0.652 \\
\hline
\end{tabular}

The level of significance for $r$ is always $\mathrm{p}<0.01$

TNB = Total number born; NBA = Number born alive

Genotype and allele frequencies and genotype distribution

The genotype and allele frequencies for the GPX5, FUT1 and ESR2 genes over all genotyped sows are presented in Table 5.

Table 5

Genotype and allele frequencies over all genotyped sows (Genotypen und Allelfrequenzen aller genotypisierten Sauen)

\begin{tabular}{lcccccc}
\hline Gene & $\mathrm{N}$ & \multicolumn{3}{c}{ Genotype frequency } & \multicolumn{3}{c}{ Allele frequency } \\
& & $\mathrm{AA}$ & $\mathrm{AB}$ & $\mathrm{BB}$ & $\mathrm{A}$ & $\mathrm{B}$ \\
\hline GPX5 & 123 & 0.057 & 0.333 & 0.610 & 0.22 & 0.78 \\
FUT1 & 120 & 0.025 & 0.292 & 0.683 & 0.17 & 0.83 \\
ESR2 & 123 & 0.130 & 0.870 & 0.000 & 0.57 & 0.43 \\
\hline
\end{tabular}


For the genes GPX5 and FUT1, expected genotype frequencies corresponded well to the observed genotype frequencies according to Hardy-Weinberg equilibrium, however, this was not the case for the ESR2 gene. According to the nearly balanced allele frequencies, one could expect, that there should be about $25 \%$ animals with the homozygous BB genotype, but no animal with this genotype was observed. Table 6 shows the distribution of the different genotypes for the GPX5, FUT1 and ESR2 genes in the two performance groups of the commercial $F_{2}$-sows. Only for the FUT1 gene, the genotype distribution between the low and the high performance group was significant different. Sows with the heterozygous AB genotype occurred significantly more often in the high performance group, whereas sows with the BB genotype occurred significantly more often in the low performance group.

Table 6

Genotype distribution of the GPX5, FUT1 and ESR2 genes in the two performance groups (Genotypenverteilung der Gene GPX5, FUT1 und ESR2 in den beiden Leistungsgruppen)

\begin{tabular}{|c|c|c|c|c|c|c|}
\hline \multirow[t]{2}{*}{ Genotype } & \multicolumn{2}{|c|}{$\begin{array}{c}\text { GPX5 } \\
\text { Performance group } \\
\end{array}$} & \multicolumn{2}{|c|}{$\begin{array}{c}\text { Gene } \\
\text { FUT1 } \\
\text { Performance group }\end{array}$} & \multicolumn{2}{|c|}{$\begin{array}{c}\text { ESR2 } \\
\text { Performance group }\end{array}$} \\
\hline & low & high & low & high & low & high \\
\hline AA & 4 & 3 & 2 & 1 & 8 & 8 \\
\hline $\mathrm{AB}$ & 24 & 17 & $11^{*}$ & $24 *$ & 54 & 53 \\
\hline $\mathrm{BB}$ & 34 & 41 & $48^{*}$ & $34 *$ & 0 & 0 \\
\hline $\begin{array}{l}\mathrm{N} / \text { Performance } \\
\text { group }\end{array}$ & 62 & 61 & 61 & 59 & 62 & 61 \\
\hline N (Total) & \multicolumn{2}{|c|}{123} & \multicolumn{2}{|c|}{$120 * *$} & \multicolumn{2}{|c|}{123} \\
\hline
\end{tabular}

* significantly different $(\mathrm{p}<0.05)$, Chi-square-test

**3 sows could not be genotyped for the FUT1 gene

\section{Discussion}

In the Figure we present the development of litter size in the two extreme performance groups. Because the selection of the sows for the two performance groups based only on the litters 2 to 4, it is interesting to note that for the first litter, litter performance was almost equal for both, the low and the high performance group. A reason for this unexpected result is probably - provided that the age of first insemination was kept constant - that the development of sows has not been finished at the age of first insemination. Therefore, genetical effects on phenotypical fecundity parameters cannot be seen entirely until the sows are not completely full-grown. This observation is important for further investigations, particularly, when gilts are investigated for reproductive traits such as uterine capacity or ovulation rate. For example, ISLER et al. (2002) observed an increased ovulation rate in sows from 17.22 corpora lutea for the first litter up to 19.92 for the third litter. The conclusion of non-genetical effects for a phenotypical trait, which does not differ at an early stage of development could be false because of confusion with unmaturity of the organism and the general physiological status of the animal, which hides a potential genetic predisposition.

Because the selection of sows based only on TNB piglets, it was interesting to evaluate the correlation between TNB and the number of NBA piglets in the two performance groups of high and low litter size (Table 4). The expectation was, that in general, the correlation between both traits was high, and, that the correlation in the high performance group should be less than in the low performance group. These 
expectations were fulfilled. However, there was a strong trend for lower correlations between TNB and the number of NBA piglets in higher litter numbers particularly for the high performance group without any exception. An explanation for these results is probably, that sows with a high potential of farrowing piglets are more susceptible to losses during farrowing or directly before, also due to non-genetical effects.

GPX5 has been mapped on SSC7 at 7(1/2)p12-p11 (BERTANI et al., 1999) and was mainly chosen as a candidate gene because many QTL for fecundity parameters such as litter size (DE KONING et al., 2001), ovulation rate (WILKIE et al., 1999) and age of puberty (CASSADY et al., 2001) were observed in this chromosomal region. Both, VAIMAN et al. (1998) and BUSKE et al. (2005) speculated of a physiological influence of this chromosomal region on fecundity parameters by the MHC class III region, however, in our population, no association between litter size and a special genotype of GPX5 was observed. From a physiological point of view, GPX5 is mainly involved in sperm quality. Therefore, GPX5 is rather involved in paternal, than in maternal fertility.

A chromosomal region for association with litter size in swine is located at the centromeric region on the q-arm of porcine chromosome 6 (YASUE et al., 1999). FUT1 has been mapped on SSC6 at 6q11 (VÖGELI et al., 1996) and is located in this region. At first, however, the FUT1 gene has been determined as a candidate gene for Escherichia coli F18 receptor locus (MEIJERINK et al., 1997). The single nucleotide polymorphism (SNP) at position 307 in exon 2 is strongly associated with oedema desease and diarrhea in swine, and therefore, with animal health. Because animal health is generally required for high fecundity, the hypothesis was, that FUT1 might also be associated with reproductive traits, such as litter size in pigs. Recently, HORÁK et al. (2005) investigated this SNP of the FUT1 gene with regard to litter size at 104 sows of the local autochthonous Czech breed. They investigated up to 6 litters for each sow and observed, that the heterozygous $A B$ and the homozygous $B B$ genotypes were the favorable ones for the traits TNB and the number of NBA piglets. Their hypothesis was, however, that the AA genotype should be beneficial on fecundity parameters due to the resistance to Escherichia coli F18 infection of this genotype. Because we also found that the $\mathrm{AB}$ genotype was favorable on litter size parameters, a pleiotropic effect of the FUT1 gene cannot be excluded. However, it is more likely, that not the FUT1 gene itself but rather another closely linked gene could be responsible for the observed results. According to VÖGELI et al. (1996), a distorted linkage disequilibrium between those genes can lead to such results, when just the beneficial genotype for resistance to Escherichia coli F18 infection is linked with another adjacent gene with unfavorable genotypes for litter size parameters.

For the ESR2 gene, Hardy-Weinberg equilibrium was not fulfilled because of the lack of any homozygous BB genotype (Table 5). One explanation could be that genotyped animals were selected $\mathrm{F}_{2}$-sows. In selected populations, deviations of genotype frequencies from the Hardy-Weinberg equilibrium should be expected for loci with impact on traits under selection (GOLIÁŠOVÁ and WOLF, 2004). Because of the lack of any homozygous BB sows in our population, a completing statement concerning a potential association between ESR2 genotypes and litter size is strictly speaking not feasible. An explanation of our results could be, that the BB genotype has been excluded from this population over years. To our knowledge, up to now, there is only one association study concerning the influence on litter size of the ESR2 gene 
(MUÑOZ et al., 2004) and no significant association was found by these authors, probably due to low animal numbers.

An additional improvement of the presented two-tail analysis would be, to extend litter size characterization by including a fifth or even a sixth litter in order to improve the reliability of phenotypes, but under our experimental conditions, this was not possible. Even if it is rather unlikely that sows of the high performance group show few offspring in the following litters or reversely, this cannot be excluded even if environmental parameters were highly standardized. In such a case, the grouping of the selected sows could be false for a few individuals, leading to problematic results with regard to an association between the frequencies of genotypes in one of the two performance groups. Therefore, a conclusion of the methodical point of view concerning two-tail analyses is generally, to characterize the phenotype as exact as possible as it is easily feasible for carcass and meat quality parameters, for example.

In a two-tail analysis, one is looking for dissimilarities for genotype distribution between two performance groups with regard to a special phenotype. However, if commercial sow populations are used, as it was the case in this study, there is often the problem that one genotype is not, or only present with extremely low animal numbers. Therefore, a comparison between rare genotypes cannot be evaluated with sufficient statistical power. Under such circumstances, statements concerning associations between phenotype and genotype are problematically. The more phenotyped animals for a certain genotype are available, the better is the expressiveness for an association between genotype and phenotype. For further research, a planned mating test would be an improvement in order to obtain more balanced genotype frequencies in the basic population (ROTHSCHILD et al., 1996). If there is a strong association between genotype and phenotype, a significant imbalance for genotypes between the two performance groups (tails) can be expected. However, planned matings are hardly imaginable when cooperating with commercial sow farms, so, in our opinion, it is essential to revert to populations, which are kept under controlled and standardized laboratory circumstances, or, even better to revert to resource populations. Considering all these facts, selection progress is mainly achieved, if firstly a beneficial polymorphism is detected for a desirable trait, and secondly, rare genotypes are detected which improve the performance in order to increase this genotype in the population.

\section{Acknowledgements}

We thank the H. Wilhelm Schaumann Stiftung (Hamburg, Germany) for the grant for B. Buske.

\section{References}

BERTANI, G.R.; MARKLUND, S.; HU, Z.L.; ROTHSCHILD, M.F.:

Rapid communication: Mapping of the Glutathione-peroxidase-5 (GPX5) gene to pig chromosome 7. J. Anim. Sci. 77 (1999), 2855-2856

BUSKE, B.; BRUNSCH, C.; ZELLER, K.; REINECKE, P.; BROCKMANN, G.:

Analysis of properdin (BF) genotypes associated with litter size in a commercial pig cross population. J. Anim. Breed. Genet. 122 (2005), 259-263

CASSADY, J.P.; JOHNSON, R.K.; POMP, D.; ROHRER, G.A.; VAN VLECK, L.D.; SPIEGEL, E.K.; GILSON, K.M.:

Identification of quantitative trait loci affecting reproduction in pigs. J. Anim. Sci. 79 (2001), 623-633 
DE KONING, D.J.; RATTINK, A.P.; HARLIZIUS, B.; GROENEN, M.A.M.; BRASCAMP, E.W.; VAN ARENDONK, J.A.M.:

Detection and characterization of quantitative trait loci for growth and reproduction traits in pigs. Livestock Production Science 72 (2001), 185-198

DEPUYDT, J.; DE SMET, ST.; GRUSPEERDT, K.; HERMAN, L.: Association study of an AvaI and PvuII polymorphism at the porcine estrogen receptor (ESR) gene with litter size. Arch. Tierz., Dummerstorf 42 (1999) Special Issue, 172-174

DRÖGEMÜLLER, C.; HAMANN, H.; THIEVEN, U.; KRIETER, J.; DISTL, O.; HARLIZIUS, B.: Influence of the genome region surrounding the estrogen receptor (ESR) gene on litter size in a German Landrace population. Arch. Tierz., Dummerstorf 42 (1999) Special Issue, 175-177

GIBSON J.P.; JIANG, Z.H.; ROBINSON, J.A.B.; ARCHIBALD, A.L.; HALEY, C.S.: No detectable association of the ESR PvuII mutation with sow productivity in a Meishan x Large White $\mathrm{F}_{2}$ population. Animal Genetics 33 (2002), 448-450

GOLIÁŠOVÁ, E.; WOLF, J.: Impact of the ESR gene on litter size and production traits in Czech Large White pigs. Animal Genetics 35 (2004), 293-297

HORÁK, P.; URBAN, T.; DVOŘÁK, J.:

The FUT1 and ESR genes - their variability and associations with reproduction in Přeštice Black-Pied sows. J. Anim. Breed. Genet. 122 (2005), 210-213

HOROGH, G.; ZSOLNAI, A.; KOMLOSI, I.; NYÍRI, A.; ANTON, I.; FÉSÜS, L.:

Oestrogen receptor genotypes and litter size in Hungarian Large White pigs. J. Anim. Breed. Genet. 122 (2005), 56-61

ISLER, B.J.; IRVIN, K.M.; NEAL, S.M.; MOELLER, S.J.; DAVIS, M.E.:

Examination of the relationship between the estrogen receptor gene and reproductive traits in pigs. J. Anim. Sci. 80 (2002), 2334-2339

KISNER, V.; MÖLLERS, B.; BRANDT, H.; GLODEK, P.:

Die Analyse von Sauenaufzuchtleistungen in der Versuchsstation Relliehausen zur Entwicklung von Kriterien der Wurfqualität. 1. Mitt.: Der Einfluss der fixen Effekte der Rassenkombination, der Wurfnummer und die Verteilung der Geburtsgewichte. Arch. Tierz., Dummerstorf 38 (1995) 1, 73-86

KMIEĆ, M.; DVOŘÁK, J.; VRTKOVÁ, I.:

Study on a relation between estrogen receptor (ESR) gene polymorphism and some pig reproduction performance characters in Polish Landrace breed. Czech J. Anim. Sci. 47 (2002) 5, 189-193

KOWALSKI, A.A.; GRADDY, L.G.; VALE-CRUZ, D.S.; CHOI, I.; KATZENELLENBOGEN, B.S.; SIMMEN, F.A.; SIMMEN, R.C.:

Molecular cloning of porcine estrogen receptor- $\beta$ complementary DNAs and developmental expression in periimplantation embryos. Biol. Reprod. 66 (2002), 760-769

MATOUŠEK, V.; KERNEROVÁ, N.; KOLAŘÍKOVÁ, O.; KŘÍŽOVÁ, I.I.; URBAN, T.; VRTKOVÁ, I.: Effect of RYR1 and ESR genotypes on the fecundity of sows of Large White breed in elite herds. Czech J. Anim. Sci. 48 (2003), 129-133

MEIJERINK, E.; FRIES, R.; VÖGELI, P.; MASABANDA, J.; WIGGER, G.; STRICKER, C.; NEUENSCHWANDER, S.; BERTSCHINGER, H.U.; STRANZINGER, G.:

Two alpha(1,2) fucosyltransferase genes on porcine chromosome $6 q 11$ are closely linked to the blood group inhibitor (S) and Escherichia coli F18 receptor (ECF18R) loci. Mamm. Genome 8 (1997) 10, 736-741

MUÑOZ, G.; ÓVILO, C.; AMILLS, M.; RODRÍGUEZ, C.:

Mapping of the porcine oestrogen receptor 2 gene and association study with litter size in Iberian pigs. Anim. Genet. 35 (2004), 242-244

VAN RENS, B.T.T.M.; VAN DER LENDE, T.:

Piglet and placental traits at term in relation to the estrogen receptor genotype in gilts. Theriogenology 57 (2002), 1651-1667

ROTHSCHILD, M.F.; JACOBSON, C.; VASKE, D.; TUGGLE, C.; WANG, L.; SHORT, T.; ECKARDT, G.; SASAKI, S.; VINCENT, A.; MCLAREN, D.; SOUTHWOOD, O.; VAN DER STEEN, H.; MILEHAM, A.; PLASTOW, G.:

The estrogen receptor locus is associated with a major gene influencing litter size in pigs. Genetics 93 (1996), 201-205

SHORT, T.H.; ROTHSCHILD, M.F.; SOUTHWOOD, O.I.; MCLAREN, D.G.; DE VRIES, A.; VAN DER

STEEN, H.; ECKARDT, G.R.; TUGGLE, C.K.; HELM, J.; VASKE, D.A.; MILEHAM, A.J.; PLASTOW, G.S.: Effect of the estrogen receptor locus on reproduction and production traits in four commercial pig lines. J. Anim. Sci. 75 (1997), 3138-3142

VAIMAN, M.; CHARDON, P.; ROTHSCHILD, M.F.:

Porcine major histocompatibility complex. Rev. Sci. Tech. Off. Int. Epizoot 17 (1998), 95-107 
VÖGELI, P.; BERTSCHINGER, H.U.; STAMM, M.; STRICKER, C.; HAGGER, C.; FRIES, R.; RAPACZ, J.; STRANZINGER, G.:

Genes specifying receptors for F18 fimbriated Escherichia coli, causing oedema disease and postweaning diarrhoea in pigs, map to chromosome 6. Anim. Genet. 27 (1996) 5, 321-328

WANG, X.; WANG, A; FU, J.; LIN, H.:

Effect of ESR1, FSHB and RBP4 genes on litter size in a Large White and a Landrace Herd. Arch. Tierz., Dummerstorf 49 (2006) 1, 64-70

WILKIE, P.J.; PASZEK, A.A.; BEATTIE, C.W.; ALEXANDER, L.J.; WHEELER, M.B.; SCHOOK, L.B.:

A genomic scan of porcine reproductive traits reveals possible quantitative trait loci (QTLs) for number of corpora lutea. Mamm. Genome 10 (1999), 573-578

YASUE, H.; MIKAWA, S.; UENISHI, H.; WADA, Y.:

Analysis of allele segregation distortion in a swine reource family. Animal Biotechnology 10 (1999) 3, $147-152$

Received: 2005-11-01

Accepted: 2006-02-13

Author's address

Dipl.-Agr. Biol. BERND BUSKE*, Dr. agr. INA STERNSTEIN,

Dr. agr. MONIKA REIßMANN, PD Dr. habil. PETER REINECKE,

Prof. Dr. habil. GUDRUN BROCKMANN

Humboldt-University of Berlin, Agricultural and Horticultural Faculty,

Institute of Animal Sciences, Department of Breeding Biology and Molecular Genetics,

Invalidenstr. 42

10115 BERLIN

GERMANY

*Corresponding Author, E-mail: bernd.buske@staff.hu-berlin.de 